\title{
17. INSOLUBLE RESIDUES OF THE FINE-GRAINED SEDIMENTS FROM THE TRENCH TRANSECT SOUTH OF GUATEMALA, DEEP SEA DRILLING PROJECT LEG $67^{1}$
}

\author{
Christiane Heinemann and Hans Füchtbauer, Geologisches Institut, Ruhr-Universität Bochum, West Germany
}

\begin{abstract}
Insoluble residues of Late Cretaceous to Quaternary deep-sea samples from slope, trench, and oceanic plate sites south of Guatemala were examined, specifically for the distribution of clay minerals in the $<2-\mu \mathrm{m}$ fraction and of silt grains in the 20-63- $\mu \mathrm{m}$ fraction. Widespread "oceanic" particles (biogenic opal, rhyolitic glass) and their diagenetic products (smectite, clinoptilolite, heulandite) were distinguished from terrigenous material-illite, kaolinite, chlorite, plagioclase, quartz, and heavy minerals. The main results of this investigation are: (1) At Site 494 on the slope immediately adjacent to the trench, terrigenous supplies testify to a slope position of the whole sequence back to the Late Cretaceous. (2) At Site 495 on the Pacific Cocos Plate, "oceanic" and terrigenous sedimentation are clearly separated. Whereas the pelagic sedimentation prevailed in the early Miocene, terrigenous minerals appeared in the middle Miocene in the clay fraction, and in the early Pliocene in the coarse silt fraction. These terrigenous supplies are interpreted as having been transported by suspension clouds crossing the slope and even the trench. The alternative, however, an eolian transport, cannot be excluded.
\end{abstract}

\section{INTRODUCTION}

Leg 67 of the Deep Sea Drilling Project investigated the convergent margin between the continental part of the Caribbean Plate and the oceanic Cocos Plate (Fig. 1). Quaternary to Upper Cretaceous sediments were encountered at the Leg 67 sites. Only the lower portions of the trench and Cocos Plate sequences were deposited above the carbonate compensation depth (CCD) and thus consist mainly of carbonate sediments.

Because one of the main objectives of this transect was to study the accretionary complex, the samples from Hole 494A, directly adjacent to the trench on its continental side, were investigated in detail.

The main objective of this paper is the mineralogical investigation of the insoluble residues of the finegrained sediments (except turbidites and possible ash layers) by X-ray and microscope. We studied the lateral and vertical distribution of clay minerals and terrigenous minerals (quartz, feldspars, zeolites, volcanic glass, and opal). Our special interest was focused on the dispersal of terrigenous sediments with respect to the trench as a possible barrier, the identification of zeolites, the refractive indexes of the volcanic glass, and possible indications of diagenesis. The number of samples we were able to study was restricted, because of the considerable time it took to adapt available methods to the requirements of our program.

\section{METHODS}

Sixty-four sediment samples were subjected to the following procedure: The carbonate was dissolved by dilute acetic acid; flocculating ions were then removed by dialysis using $\mathrm{n} / 100 \mathrm{NH}_{4} \mathrm{OH}$. The fraction $>63 \mu \mathrm{m}$ was collected by sieving. Because of its small amount or even its absence, this fraction was not studied further. Instead, we used the $20-$ to $60-\mu \mathrm{m}$ fraction for microscopic analyses; the $<2-\mu \mathrm{m}$ fraction

${ }^{1}$ Aubouin, J., von Huene, R., et al., Init. Repts. DSDP, 67: Washington (U.S. Govt. Printing Office). (only one Atterberg separation!) was examined by X-ray. A suspension of the latter fraction was allowed to dry on a slide. Then it was $\mathrm{X}$-rayed untreated and glycolated, as well as after heating to $370^{\circ} \mathrm{C}$ (for dewatering of smectites) and in some cases to $500^{\circ} \mathrm{C}$ (in order to destroy the kaolinite).

The grain-size fractions were only roughly estimated (Table 1 ) on the basis of the volume of the powder; the "total carbonate" was taken from the shipboard files; where no figures are given, the main sediment was indicated, according to the core descriptions. Silt-size clay mineral aggregates occur especially in those samples with low percentages of 20 to $63-\mu \mathrm{m}$ fractions.

Before the microscopic inspection of the coarse silt fraction (20-63 $\mu \mathrm{m})$, opal and zeolites were separated from feldspars and quartz by centrifuging in a mixture of methanol and bromoform with a density of $D=2.43 \mathrm{~g} \cdot \mathrm{cm}^{-3}$. This separation was quite effective for the enrichment of zeolites and opal in the light fraction. It proved less effective for feldspars; these could not be kept completely out of the light fraction, but they were counted only in the heavy fraction. Glass occurred in both fractions. The only advantage of the separation was the enrichment of zeolites. As a whole, however, this method cannot be recommended, because it is now difficult or impossible to calculate the modal composition of the samples and the abundance of the individual species in the entire population. The reason is that the fractions were not weighed because of their very small weight and because of the occurrence of clay aggregates in both fractions. In general, the heavy fraction $(D>2.43)$ is equal or a little higher in weight than the light fraction. The values in Table 3 and Figures 4 to 6 are therefore only good for lateral and vertical comparison.

The heavy fraction was counted under the polarizing microscope in immersion oils with $n=1.56$ (separation of plagioclase groups) and $n=1.54$ (identification of quartz); the light fraction was counted in an immersion oil with $n=1.49$ in order to distinguish zeolites and glass (see the following sections). In each fraction 100 grains were counted. A number of samples was X-rayed for zeolites. Single crystals of zeolite were mounted on a Gandolfi X-ray camera and identified using all spacings.

\section{MINERALOGY}

The following species were identified in the 20- to $63-\mu \mathrm{m}$ fraction.

\section{Opal-A}

With a density below 2.43 and a refractive index well below 1.49, opal-A is isotropic and shows a broad X-ray peak between $17^{\circ}$ and $30^{\circ}\left(2 \theta, \mathrm{CuK}_{\alpha}\right)$. Opal-A is only 


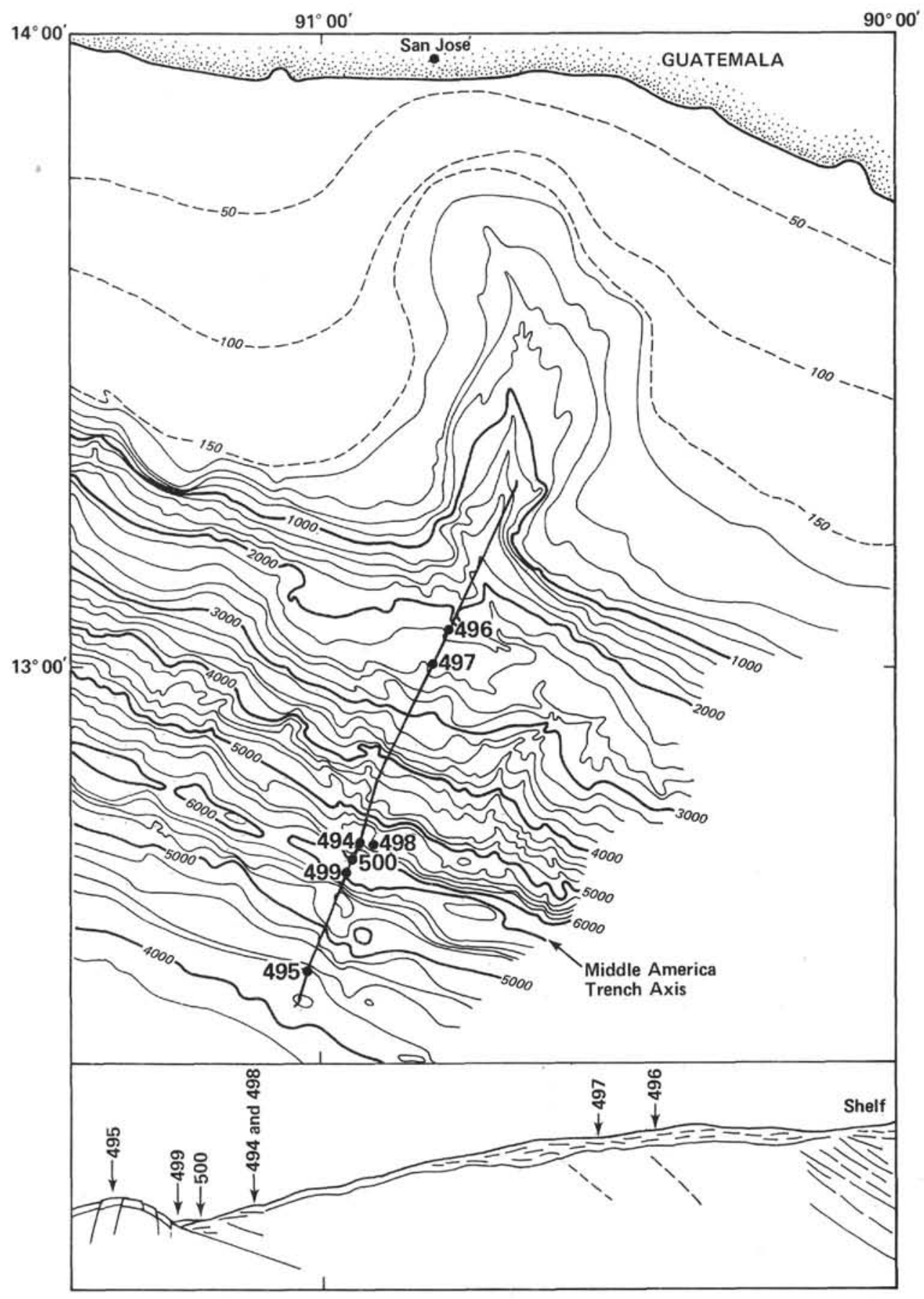

Figure 1. Location of Leg 67 sites south of Guatemala.

found as microfossil tests, i.e., radiolarians (Spumellaria and cup-shaped Nasselaria), diatoms, sponge spicules, and isolated silicoflagellates. Radiolarian fragments can be found in the 2- to $6-\mu \mathrm{m}$ fraction, though glass seems to be more frequent in this fine silt fraction.

Opal-CT, characterized by its higher refractive index (1.44-1.48 compared with 1.40-1.44 for opal-A; Keene, 1976), by a small birefringence, and by two X-ray peaks between $20^{\circ}$ and $23^{\circ}$ ( $2 \theta$; von Rad et al., 1977), was not found in our samples.

\section{Zeolites}

In the $D<2.43$ fraction, the following two zeolites were identified optically: clinoptilolite: $n<1.49$ (nearly isotropic); and heulandite: $n>1.49$ (slightly birefringent). This identification was confirmed by X-ray analyses of several samples that were heated overnight to $450^{\circ} \mathrm{C}$ (Table 2). According to Alietti (1972), only the heulandite lattice should be more or less destroyed after this procedure. 
Table 1. Grain size and carbonate (roughly estimated percentages).

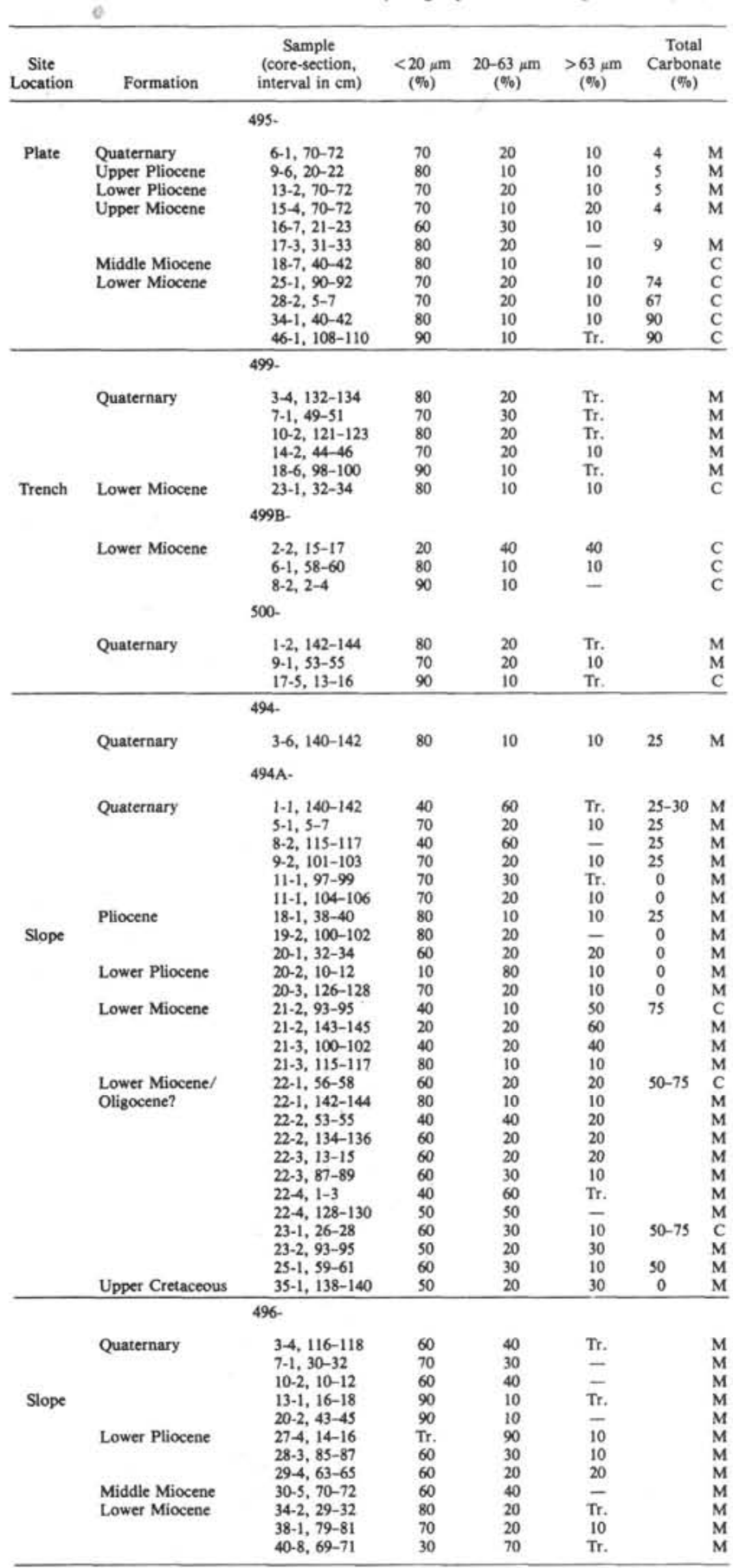

Note: $\mathrm{M}=$ mud, poor in carbonate; $\mathrm{C}=$ carbonate ooze; $\mathrm{Tr} .=$ trace; $-=$ absent.
The agreement between X-ray and optical identification is fair, provided that heulandite is concealed by clinoptilolite in the X-ray diagram of Sample 499-7-1, 49-51 cm. A single heulandite crystal mounted on a Gandolfi camera revealed the spacings $8.93,8.02,6.86$, $3.98,3.70,2.81 \AA$, which are in agreement with the spacings of a heulandite from Herborn-Seelbach (Germany) and with the computer-refined spacings of the ASTM 25-144 Ca-heulandite (Dr. G. Oehlschlegel, personal communication, 1980).

Most zeolite grains are irregular to subrounded, in part elongate, occasionally with rugged surfaces and diameters between 30 and $40 \mu \mathrm{m}$ (Fig. 2). Euhedral grains, however, occur in places.

\section{Glass}

Glass occurs in the density fractions both below and above 2.43 . The refractive index varies between 1.48 and 1.54. Cumulative curves (Fig. 3) were plotted from determinations of about 100 shards in each immersion; the number of grains with higher and lower refractive indexes than the immersion oil was counted. The median refractive indexes are between 1.498 and 1.513 , as indicated in the diagrams. This corresponds to rhyolitic composition (Schmincke, in press, fig. 5). Shards below $n=1.53$ are colorless, whereas brownish shards have $n>1.53$, which is in full agreement with Schmincke (in press). The refractive indexes of tubular pumice are similar to the rest of the colorless shards. The refractive indexes of the shards in the light fraction do not differ significantly from those in the heavy fraction. Bubble
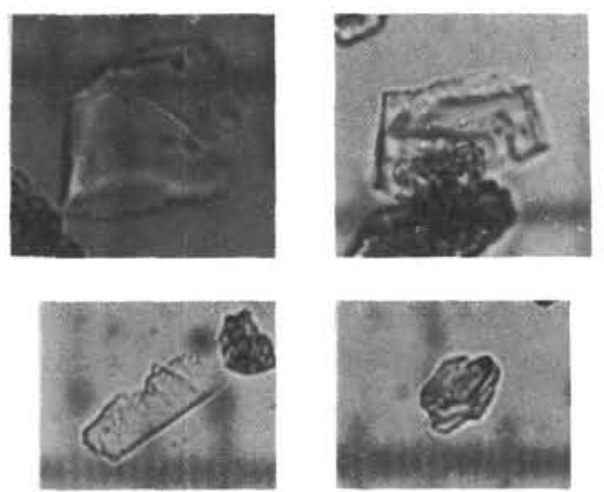

Figure 2. Four zeolite grains. (Top: clinoptilolites [size: $40 \mu \mathrm{m}$ ]; bottom: heulandites [size: left, $70 \mu \mathrm{m}$, right, $50 \mu \mathrm{m}$ ]. The zeolites are the transparent grains.)

Table 2. Comparison of the intensity of 020 spacings and optical identification of zeolites.

\begin{tabular}{|c|c|c|c|c|c|c|}
\hline \multirow{2}{*}{$\begin{array}{c}\text { Sample } \\
\text { (hole-core-section, } \\
\text { interval in } \mathrm{cm} \text { ) }\end{array}$} & \multirow{2}{*}{$\begin{array}{c}\text { Untreated } \\
(\AA)\end{array}$} & \multirow[b]{2}{*}{$250^{\circ} \mathrm{C}$} & \multirow[b]{2}{*}{$450^{\circ} \mathrm{C}$} & \multirow[b]{2}{*}{ Interpretation } & \multicolumn{2}{|c|}{ Optical Identification } \\
\hline & & & & & Heulandite & Clinoptilolite \\
\hline $496-40-8$ & Strong (8.95) & Medium & Weak & Heulandite & $7^{\mathrm{a}}$ & $1^{\mathrm{a}}$ \\
\hline 494A-9-2 & Strong $(9.06)$ & Weak & Absent & Heulandite & 5 & 10 \\
\hline 494A-9-2 & Strong (8.99) & Medium & Medium & Clinoptilolite\} & 3 & 10 \\
\hline $499-7-1,49-51$ & Strong (8.95) & Strong & Strong & Clinoptilolite & 11 & 18 \\
\hline $499-10-2$ & Strong $(8.90)$ & Medium & Strong & Clinoptilolite & 2 & 52 \\
\hline
\end{tabular}

a Numbers are counted grains. 


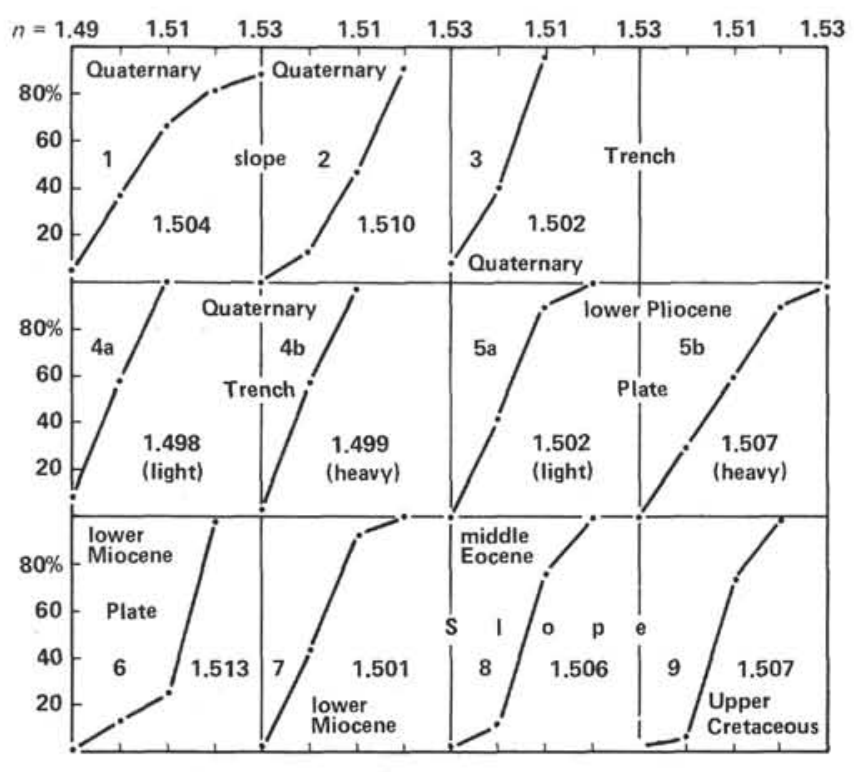

Figure 3. Cumulative curves of refractive indexes of colorless glass shards. $(1=$ Sample 496-7-1, 30-32 cm; 2 = Sample 494A-11-1, 97-99 cm; 3 = Sample 500-9-1, 53-55 cm; $4=499-14-2,44-46 \mathrm{~cm}$; $5=$ Sample 495-13-2, 70-72 cm; $6=$ Sample 495-46-1, 108-110 $\mathrm{cm} ; 7$ = Sample 494A-21-2, 143-145 cm; 8 = Sample 494A-23-2, 93-95 cm; $9=$ Sample $494 \mathrm{~A}-35-1,138-140 \mathrm{~cm}$. Where not indicated, the light fraction was used.)

junction shards are less frequent than tubular pumice. Palagonite was not detected.

Glass is also frequent in finer fractions, for example, 2 to $6 \mu \mathrm{m}$; glass may also be the main source of the broad reflection between $19^{\circ}$ to $21^{\circ}$ and $32^{\circ}(2 \theta)$ in the $<2-\mu$ m fraction.

\section{Feldspars}

Lath-shaped or irregular, feldspars have occasionally twinned or zoned grains with a density higher than 2.43 . Undulatory extinction occurs. Three groups were separated under the microscope: $n>1.56, n=1.56$ (about $n_{\mathrm{y}}$ and $n_{\mathrm{z}}$ of labradorite), and $n<1.56$. The last group is often rich in small inclusions; feldspars with $n<1.54$ are missing; only plagioclases occur. As shown in Figure 4 , the feldspars are symmetrically distributed around $n=1.56$, which is in harmony with andesites as source rocks.

\section{Quartz}

Quartz is enriched in the density $>2.43$ fraction and characterized by X-ray peaks at $26.6^{\circ}$ and $20.8^{\circ} 2 \theta$. Quartz occurs only in small amounts, always less than $5 \%$ of the total sediment, in Holes 494A, 496, and 500 (Fig. 4).

\section{Accessory Minerals}

Small quantities of heavy minerals (especially amphiboles), biotite, and fish remains (brownish phosphorite) were found in many samples.

\section{Clay Minerals}

Clay minerals were identified in the $<2-\mu \mathrm{m}$ fraction by X-ray diffraction (XRD) (Table 3 ). The main clay mineral in all samples is smectite. Because only the 001 spacings are developed, it is, according to Reynolds and Hower (1970), not possible to exclude a mixed-layer illite-smectite with a high percentage of expanded layers. We suggest that the other spacings are missing as a result of poor ordering of the lattice. Because only the first Atterberg separation was used, the main grain size of this powder was well below $2 \mu \mathrm{m}$. Admixtures of opal and/or glass, though present in most clay fractions according to XRD, would not explain the deficiency of the above-mentioned spacings.

Minor amounts of illite and kaolinite and/or chlorite are present in many samples. Because of the low percentages, it was not possible to distinguish kaolinite from chlorite directly using the spacings of $d=3.58$ for kaolinite and $d=3.50-3.55$ for chlorite. Relative percentages of clay minerals were calculated from the peak areas (Biscaye, 1965) using factors 1, 2, 2, 4 for smectite, kaolinite, chlorite, and illite, respectively.

\section{DIAGENESIS}

\section{Opal}

No clear-cut evidence for diagenetic alteration of opaline tests, i.e., no opal-CT, was found. The refractive indexes of different species of radiolarians and diatoms that show considerable differences in young sediments seem to be more homogeneous and to increase with age; they approach values around 1.44 or higher. The interpretation of these preliminary observations is unclear, however.

\section{Zeolites}

With a few exceptions, high silica zeolites (clinoptilolite and heulandite) show a uniform distribution in all Leg 67 holes.

There is no clear tendency of the heulandite-clinoptilolite ratio to increase or decrease with depth. The quantity of zeolites is lower than $10 \%$ in the $D<2.43$ fraction (Fig. 5) and lower than $5 \%$ in the insoluble residues; only in the trench Holes 499 and 500, enrichments occur. The absence of phillipsite may be due to the paucity of basaltic glass, the "advanced" age of most of the sediments studied, the depth of burial, and the high sedimentation rate (all of these factors control the growth of phillipsite) (Boles and Wise, 1978; Kastner and Stonecipher, 1978). Clinoptilolite is the most common zeolite in marine sediments older than middle Tertiary and at sub-bottom depths exceeding ca. 150 meters (Boles and Wise, 1978; Kastner and Stonecipher, 1978). It is generally interpreted as a diageneitc mineral formed in situ from pore solutions, with rhyolitic glass as a possible but not necessary precursor (Boles and Wise, 1978; Kastner and Stonecipher, 1978). The abundance of clinoptilolite in smectite-rich sediments suggests a volcanic source (Kastner and Stonecipher, 1978).

The manganiferous chalk in the basal unit of Hole 495 contains euhedral clinoptilolite crystals that certainly are authigenic. A recrystallization of smectite is also seen in this sample. In general, however, the zeolite grains are irregular to subrounded and frequently show an aggregate birefringence. The grain shape suggests a 


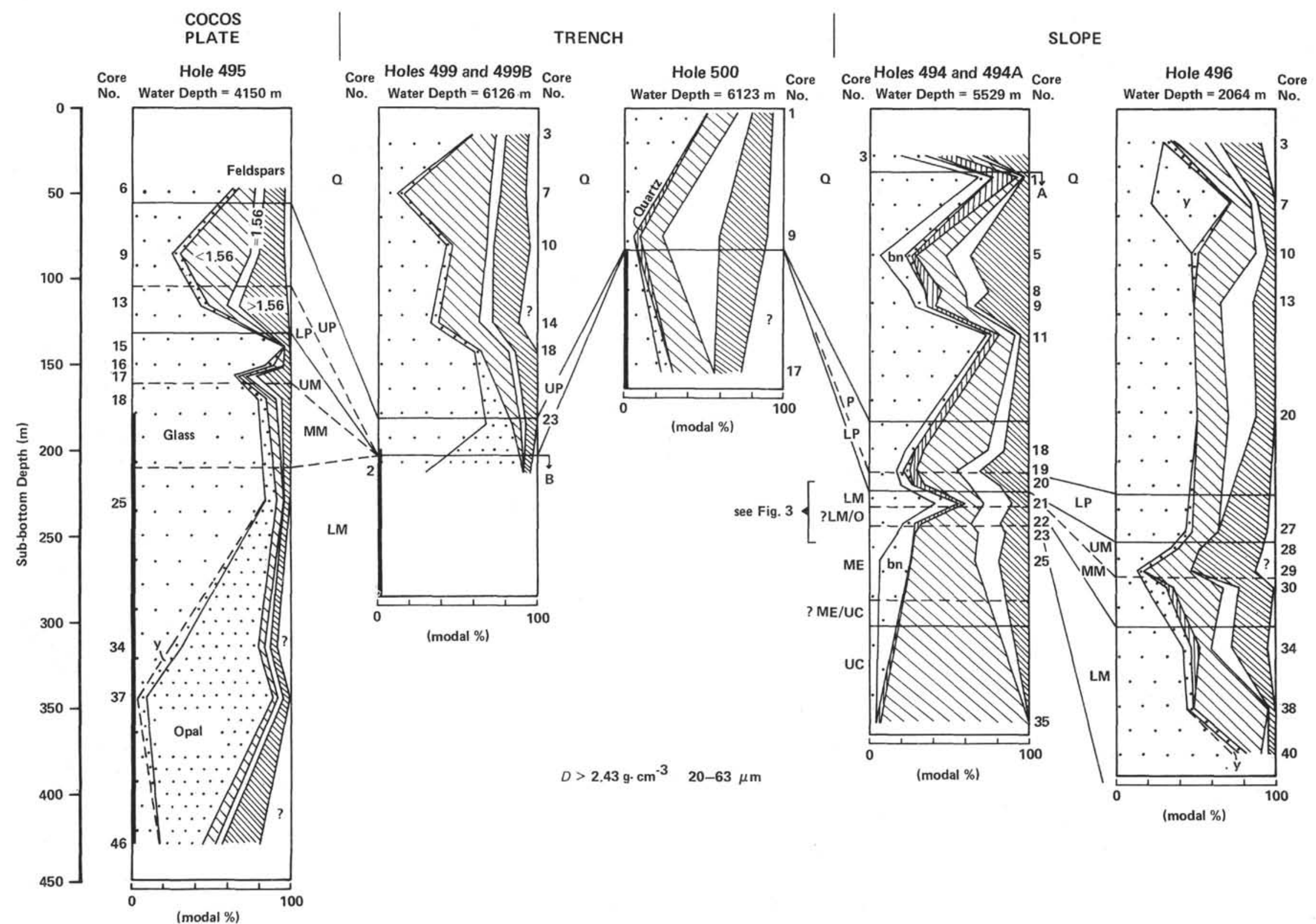

Figure 4. Heavy fraction of the insoluble residue, 20 to $63 \mu \mathrm{m}$, modal percent. (For Holes 494 and 494A, only average values are plotted; for individual samples see Fig. 7. Bar on left side indicates carbonate sediments. Abbreviations: A with arrow = start of Hole 494A samples. B with arrow = start of Hole 499B samples. Q = Quaternary; UP, LP = upper, lower Pliocene; $\mathrm{UM}, \mathrm{MM}, \mathrm{LM}=$ upper, middle, lower Miocene; $\mathrm{O}=$ Oligocene; $\mathrm{ME}=$ middle Eocene; $\mathrm{UC}=$ Upper Cretaceous; $\mathrm{bn}, \mathrm{y}=$ brown, yellow glass; $\mathrm{t}=$ tubular pumice; $\mathrm{H}=$ heulandite; $\mathrm{C}$ = clinoptilolite. $?=$ minor components or undetermined.) 
Table 3. Clay minerals in Leg 67 samples.

\begin{tabular}{|c|c|c|c|c|c|c|c|c|}
\hline \multirow[b]{2}{*}{ Location } & \multirow[b]{2}{*}{ Formation } & \multirow{2}{*}{$\begin{array}{c}\text { Sample } \\
\text { (interval in cm) }\end{array}$} & \multirow{2}{*}{$\begin{array}{l}\text { Sub-bottom } \\
\text { Depth (m) }\end{array}$} & \multicolumn{2}{|c|}{ Swelling Minerals $(\dot{\mathrm{A}})$} & \multicolumn{3}{|c|}{ Clay Minerals $(\%)$} \\
\hline & & & & Original & Glycolated & Smectite & Illite & Kaolinite, Chlorite ${ }^{\mathrm{a}}$ \\
\hline \multirow{42}{*}{ Slope } & \multirow[t]{5}{*}{ Quaternary } & $496-3-4,116-118$ & 22.7 & 13.8 & 17.3 & 58 & 14 & $28-, c$ \\
\hline & & $496-7-1,30-32$ & 55.3 & 13.9 & 16.9 & 61 & 19 & $20 \mathrm{k},-$ \\
\hline & & $496-10-2,10-12$ & 85.1 & 14.0 & 16.3 & 66 & 17 & $17 \mathrm{k},-$ \\
\hline & & $496-13-1,16-18$ & 112.2 & 13.6 & 16.7 & 60 & - & $40(\mathrm{k}),-$ \\
\hline & & $496-20-2,43-45$ & 180.4 & 13.6 & 17.0 & 83 & - & $17 \mathrm{k},-$ \\
\hline & \multirow{2}{*}{$\begin{array}{l}\text { Lower } \\
\text { Pliocene } \\
\text { Upper } \\
\text { Miocene }\end{array}$} & $496-27-4,14-16$ & 249.7 & 13.7 & 17.2 & 78 & 15 & $7 \mathrm{k},-$ \\
\hline & & $496-29-4,63-65$ & 269.1 & 13.2 & 18.0 & 45 & 22 & $33 \mathrm{k},-$ \\
\hline & \multirow{5}{*}{$\begin{array}{l}\text { Middle } \\
\text { Miocene } \\
\text { Lower } \\
\text { Miocene }\end{array}$} & $496-30-5,70-72$ & 280.2 & 13.3 & 16.9 & 70 & 12 & $18 \mathrm{k},-$ \\
\hline & & $496-34-2,29-32$ & 313.2 & 13.4 & 16.9 & 60 & + & $40 \mathrm{k},-$ \\
\hline & & $496-35-2,56-58$ & 223.1 & 15.3 & 17.3 & 64 & 18 & $18 \mathrm{k},-$ \\
\hline & & $496-38-1,79-81$ & 350.3 & 14.0 & 17.3 & 82 & 7 & $11 \mathrm{k},-$ \\
\hline & & $496-40-8,69-71$ & 379.7 & 13.7 & 17.3 & 70 & 10 & $20 \mathrm{k},-$ \\
\hline & & $494-3-6,140-142$ & 27.4 & 15,4 & 17.4 & 75 & 10 & $15 \mathrm{k},-$ \\
\hline & \multirow{6}{*}{ Quaternary } & $494 \mathrm{~A}-1-1,140-142$ & 40.4 & 13.1 & 16.9 & 63 & 21 & $16 \mathrm{k},-$ \\
\hline & & $494 A-5-1,5-7$ & 75.5 & 13.2 & 17.3 & 65 & 23 & $12 \mathrm{k}, \mathrm{c}$ \\
\hline & & $494 \mathrm{~A}-8-2,115-117$ & 106.6 & 14.7 & 16.7 & 37 & 42 & $21 \mathrm{k},-$ \\
\hline & & 494A-9-2, 101-103 & 116.0 & 15.2 & 16.9 & 61 & 26 & $13 \mathrm{k},-$ \\
\hline & & $494 \mathrm{~A}-11-1,97-99$ & 133.5 & 13.6 & 17.2 & 61 & 22 & $17 \mathrm{k},-$ \\
\hline & & $494 \mathrm{~A}-11-1,104-106$ & 133.55 & 16.0 & 17.3 & 60 & 13 & $27 \mathrm{k}, \mathrm{c}$ \\
\hline & \multirow[t]{2}{*}{ Pliocene } & $494 \mathrm{~A}-18-1,38-40$ & 199.4 & 12.2 & 16.7 & 69 & 14 & $17 \mathrm{k},-$ \\
\hline & & $494 \mathrm{~A}-19-2,100-102$ & 211.0 & 14.7 & 17.2 & 77 & 13 & $10 \mathrm{k},-$ \\
\hline & Lower & $494 \mathrm{~A}-20-1,32-34$ & 218.3 & 14.7 & 16.7 & 64 & 14 & $22 \mathrm{k}, \mathrm{c}$ \\
\hline & Pliocene & $494 \mathrm{~A}-20-1,89-91$ & 218.8 & 13.3 & 17.0 & 65 & 21 & $14 \mathrm{k},-$ \\
\hline & & $494 \mathrm{~A}-20-2,10-12$ & 219.6 & 13.4 & 17.3 & 63 & 20 & $17 \mathrm{k},-$ \\
\hline & & $494 \mathrm{~A}-20-3,37-39$ & 221.4 & 14.1 & 17.0 & 50 & 33 & $17 \mathrm{k},-$ \\
\hline & & $494 \mathrm{~A}-20-3,126-128$ & 222.7 & 13.4 & 16.7 & 47 & 42 & $11 \mathrm{k},-$ \\
\hline & Lower & $494 \mathrm{~A}-21-2,93-95$ & 229.9 & 15.0 & 17.4 & 64 & 24 & $12 \mathrm{k},-$ \\
\hline & Pliocene & $494 \mathrm{~A}-21-2,143-145$ & 230.4 & 14.2 & 17.5 & 66 & 17 & $17 \mathrm{k}, \mathrm{c}$ \\
\hline & & $494 \mathrm{~A}-21-3,100-102$ & 231.5 & 15.6 & 17.2 & 55 & 13 & $32 \mathrm{k},-$ \\
\hline & & $494 \mathrm{~A}-21-3,115-117$ & 231.6 & 15.0 & 17.3 & 91 & 6 & $3 \mathrm{k}, \mathrm{c}$ \\
\hline & Lower & $494 \mathrm{~A}-22-1,56-58$ & 237.6 & 15.1 & 17.2 & 85 & 10 & $5 \mathrm{k}, \mathrm{c}$ \\
\hline & Miocene & $494 \mathrm{~A}-22-1,142-144$ & 238.5 & 14.8 & 17.3 & 68 & 21 & $11 \mathrm{k},-$ \\
\hline & & $494 \mathrm{~A}-22-2,53-55$ & 239.0 & 15.1 & 17.3 & 75 & 18 & $7 \mathrm{k},-$ \\
\hline & Oligo- & $494 \mathrm{~A}-22-2,134-136$ & 239.8 & 15.0 & 17.3 & 76 & 12 & $12 \mathrm{k},-$ \\
\hline & cene(?) & $494 \mathrm{~A}-22-3,13-15$ & 240.1 & 14.7 & 17.1 & 74 & 9 & $17 \mathrm{k},-$ \\
\hline & & $494 \mathrm{~A}-22-3,87-89$ & 240.9 & 13.6 & 16.7 & 52 & 41 & $7 \mathrm{k}, \mathrm{c}$ \\
\hline & & $494 \mathrm{~A}-22-4,1-3$ & 241.5 & 11.7 & 17.2 & $<100$ & + & $+\mathrm{k},-$ \\
\hline & & $494 \mathrm{~A}-22-4,128-130$ & 242.8 & 13.1 & 17.3 & 73 & 27 &,$+- \mathrm{c}$ \\
\hline & Middle Eo- & $494 \mathrm{~A}-23-1,26-28$ & 246.8 & 13.2 & 16.9 & 83 & 17 & $+\mathrm{k},-$ \\
\hline & cene/Upper & $494 \mathrm{~A}-23-2,93-95$ & 248.9 & 14.7 & 17.2 & 86 & 14 & - \\
\hline & $\begin{array}{l}\text { Creta- } \\
\text { ceous(?) }\end{array}$ & $494 \mathrm{~A}-25-1,59-61$ & 266.0 & 15.1 & 17.3 & 88 & 12 & - \\
\hline & $\begin{array}{l}\text { Upper } \\
\text { Cretaceous }\end{array}$ & $494 \mathrm{~A}-35-1,138-140$ & 358.8 & 14.2 & 16.7 & 80 & - & $20 \mathrm{k}, \mathrm{c}$ \\
\hline & Quaternary & $500-1-2,142-144$ & 2.9 & 13.9 & 17.0 & 100 & - & - \\
\hline & & $500-9-1,53-55$ & 71.5 & 14.0 & 19.2 & 58 & 28 & 14 \\
\hline & $\begin{array}{l}\text { Lower } \\
\text { Miocene }\end{array}$ & $500-17-5,13-16$ & 153.1 & 13.6 & 17.3 & 100 & - & - \\
\hline & Quaternary & $499-3-4,132-134$ & 16.8 & 13.8 & 16.8 & 78 & $(+)$ & $22 \mathrm{k},-$ \\
\hline & & $499-7-1,49-51$ & 49.5 & 13.9 & 17.3 & 84 & $(+)$ & $16 \mathrm{k},-$ \\
\hline & & $499-10-2,121-123$ & 80.2 & 14.0 & 17.0 & 84 & $(+)$ & $16 \mathrm{k},-$ \\
\hline Trench & & $\begin{array}{l}499-14-2,44-46 \\
499-18-6,98-100\end{array}$ & $\begin{array}{l}116.4 \\
161.0\end{array}$ & 13.8 & $\begin{array}{l}16.7 \\
17.0\end{array}$ & $\begin{array}{l}64 \\
86\end{array}$ & + & $36 \mathrm{k},-$ \\
\hline & Upper & $499-23-1,32-34$ & & 13.0 & $\begin{array}{l}17.0 \\
16.6\end{array}$ & 58 & + & $14 \mathrm{k},-$ \\
\hline & Pliocene & $499-23-1,32-34$ & 200.3 & 13.6 & 16.6 & 54 & 31 & $15 \mathrm{k},-$ \\
\hline & Lower & 499B-2-2, 15-17 & 211.7 & 14.0 & 17.2 & 100 & $(+)$ & - \\
\hline & Miocene & $\begin{array}{l}499 \mathrm{~B}-6-1,58-60 \\
499 \mathrm{~B}-8-2,2-4\end{array}$ & $\begin{array}{l}248.6 \\
268.5\end{array}$ & $\begin{array}{l}12.2 \\
13.6\end{array}$ & $\begin{array}{l}17.6 \\
17.3\end{array}$ & $\begin{array}{r}94 \\
100\end{array}$ & $\frac{6}{-}$ & $\bar{z}$ \\
\hline & Quaternary & $495-6-1,70-72$ & 48.2 & 15.7 & 17.3 & 89 & - & $11 \mathrm{k}_{\mathrm{s}}-$ \\
\hline & $\begin{array}{l}\text { Upper } \\
\text { Pliocene }\end{array}$ & $495-9-6,20-22$ & 83.7 & 13.4 & 16.9 & 71 & 23 & $6 \mathrm{k},-$ \\
\hline Plate & $\begin{array}{l}\text { Lower } \\
\text { Pliocene }\end{array}$ & $495-13-2,70-72$ & 116.2 & 13.2 & 17.1 & 69 & 25 & $6 \mathrm{k},-$ \\
\hline & $\begin{array}{l}\text { PUocene } \\
\text { Upper } \\
\text { Miocene }\end{array}$ & $495-16-7,21-23$ & 151.7 & 13.2 & 17.4 & 78 & $(+)$ & $22 \mathrm{k},-$ \\
\hline & $\begin{array}{l}\text { Middle } \\
\text { Miocene }\end{array}$ & $495-18-7,40-42$ & 170.9 & 13.3 & 19.2 & 60 & 40 & $(+) \mathrm{k}_{,}-$ \\
\hline & Lower & $495-25-1,90-92$ & 228.9 & 15.0 & 16.8 & $<100$ & $(+)$ & - \\
\hline & Miocene & $495-28-2,5-7$ & 258.1 & 13.2 & 17.1 & $<100$ & $(+)$ & - \\
\hline & & $495-34-1,40-42$ & 313.9 & 14.0 & 17.5 & $<100$ & $(+)$ & - \\
\hline & & $495-37-2,4-6$ & 343.5 & 14.2 & 17.1 & $<100$ & $(+)$ & - \\
\hline & & $495-46-1,108-110$ & 428.5 & 12.1 & 16.4 & 96 & - & $4 \mathrm{k},-$ \\
\hline
\end{tabular}

detrital origin, although this is unlikely according to Iijima (1978) because of the instability of the grains in meteoric water. In addition, the uniform distribution even in sites far from land makes such an interpretation improbable.

\section{Smectite}

An authigenic origin for the swelling clays is suggested (1) by fibrous and in part spheroidal growth forms, although a cryptocrystalline fabric is also com- mon, and (2) by the invariably high smectite content of all samples, even in the Cocos-Plate sequences, during the deposition of which this Plate was a great distance from the continent.

Smectite probably formed from very fine-grained volcanic glass that, according to XRD, occurs even in the $<2-\mu \mathrm{m}$ fraction. Silt-sized glass shards are generally fresh, but this does not contradict our interpretation, because reaction rates are very much faster in the clay grain-size fraction due to the large surface areas. 


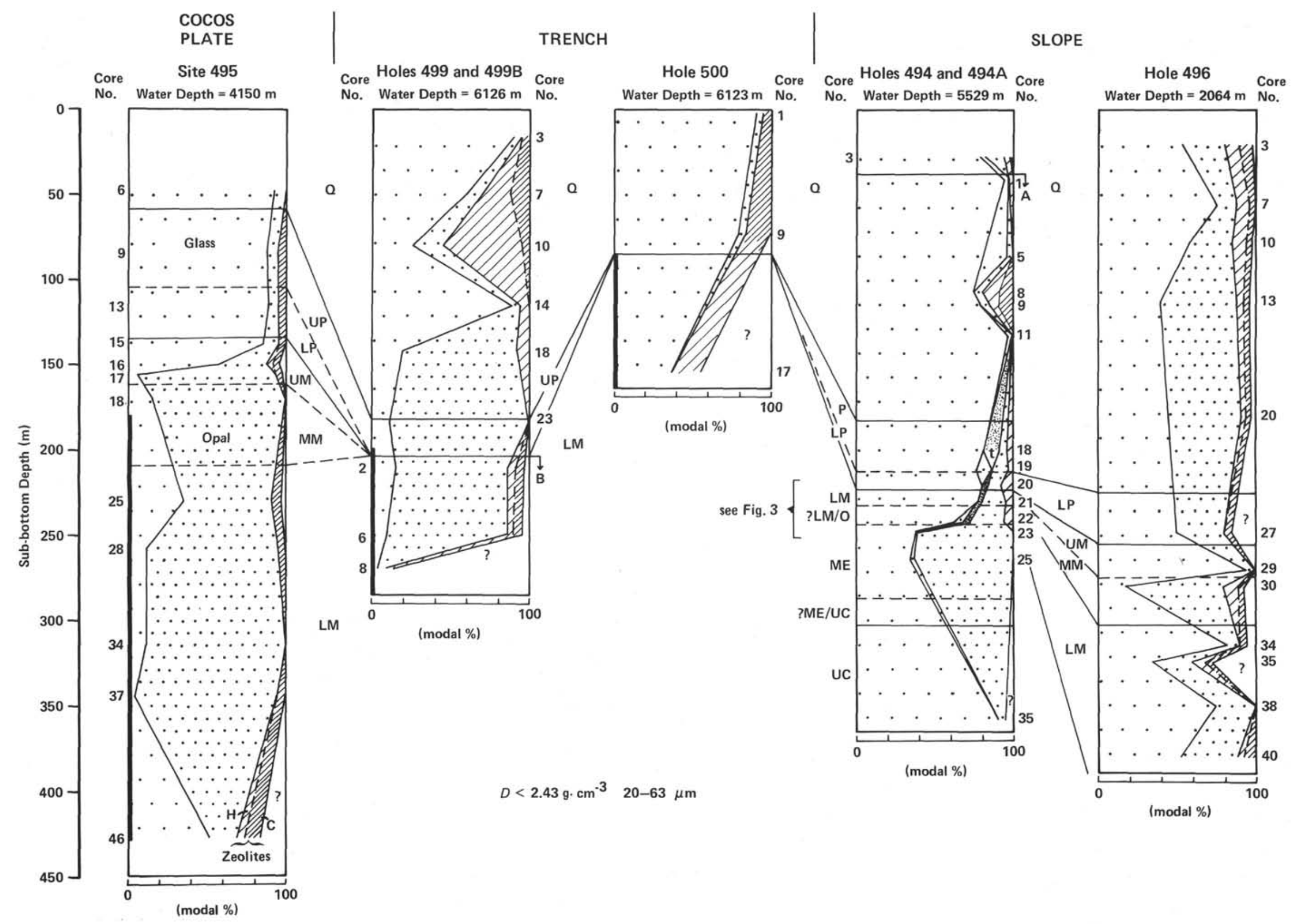




\section{Other Diagenetic Influences}

Diagenetic alterations not considered in this report include the organic matter and the formation of carbonate concretions and pyrite. Gas hydrates are an important agent in diagenesis (R. Hesse, personal communication, 1980; Harrison et al., this volume).

\section{DISTRIBUTION}

\section{Cocos Plate (Site 495)}

In the early and middle Miocene, this site was near the spreading center and, as its calcareous sequence indicates, above the CCD. There is no indication of terrigenous sediment reaching this area at that time. Skeletal opal, volcanic glass, and smectite constitute the insoluble residue of the chalk and the calcareous ooze. In the lowermost sample, from the manganiferous chalk, most of the volcanic glass belongs to the intermediate range ( $n=1.51-1.52$; Fig. 3 , No. 6$)$. The source of these shards may partially be different from that of the shards from the slope.

In the middle Miocene, when the site subsided below the CCD and abyssal clay was deposited, the first terrigenous influences appeared, as shown by an admixture of illite and kaolinite in the clay fraction (Table 3 and Fig. 6). According to Thompson (this volume), the sedimentation rate was at its lowest point at this time, i.e., between the end of the carbonate sedimentation and the onset of a strong terrigenous supply. The latter may be the result of eolian or aquatic transport. According to Windom (1969), the oceans may presently receive as much as $25 \%$ to $75 \%$ of their detrital phases from atmospheric dust fallout consisting of mica, quartz (about $4 \mu \mathrm{m}$ in size), feldspar, chlorite, and kaolinite. It is, however, difficult to understand why this fallout did not begin before the middle Miocene at Site 495 and in the trench when it had already occurred in the early Miocene and the Oligocene at the slope sites. The alternatives would be transportation (1) by the North Equatorial Current, a westerly surface current in the vicinity of Site 495 since the middle Miocene, according to $\mathrm{H}$. Beiersdorf (personal communication, 1981), (2) by midwater currents, which, according to Seibold (1978), may provide a lateral transport of thousands of kilometers, or (3) by nepheloid layers up to 2000 meters thick creeping down the continental slope or caused by turbidity currents (Seibold, 1978); such layers are tentatively outlined in Figure 6.

Beginning in the late Miocene, the sedimentation rate increased until the Quaternary, and volcanic glass became more abundant than skeletal opal in the light fraction (Fig. 5). According to Pichler et al. (1973), volcanism began in Guatemala to Nicaragua during the middle Tertiary. In the Miocene, large quantities of rhyolitic ignimbrites erupted. It is therefore suggested that the increase in the quantity of glass shards at Site 495 is mainly caused by an increase in volcanic activity in Middle America at this time, that is, about the late Miocene. If subduction was active at least since the later Miocene, about $10 \mathrm{Ma}, 875 \mathrm{~km}$ of ocean plate would have passed through the trench since, according to the spreading rate

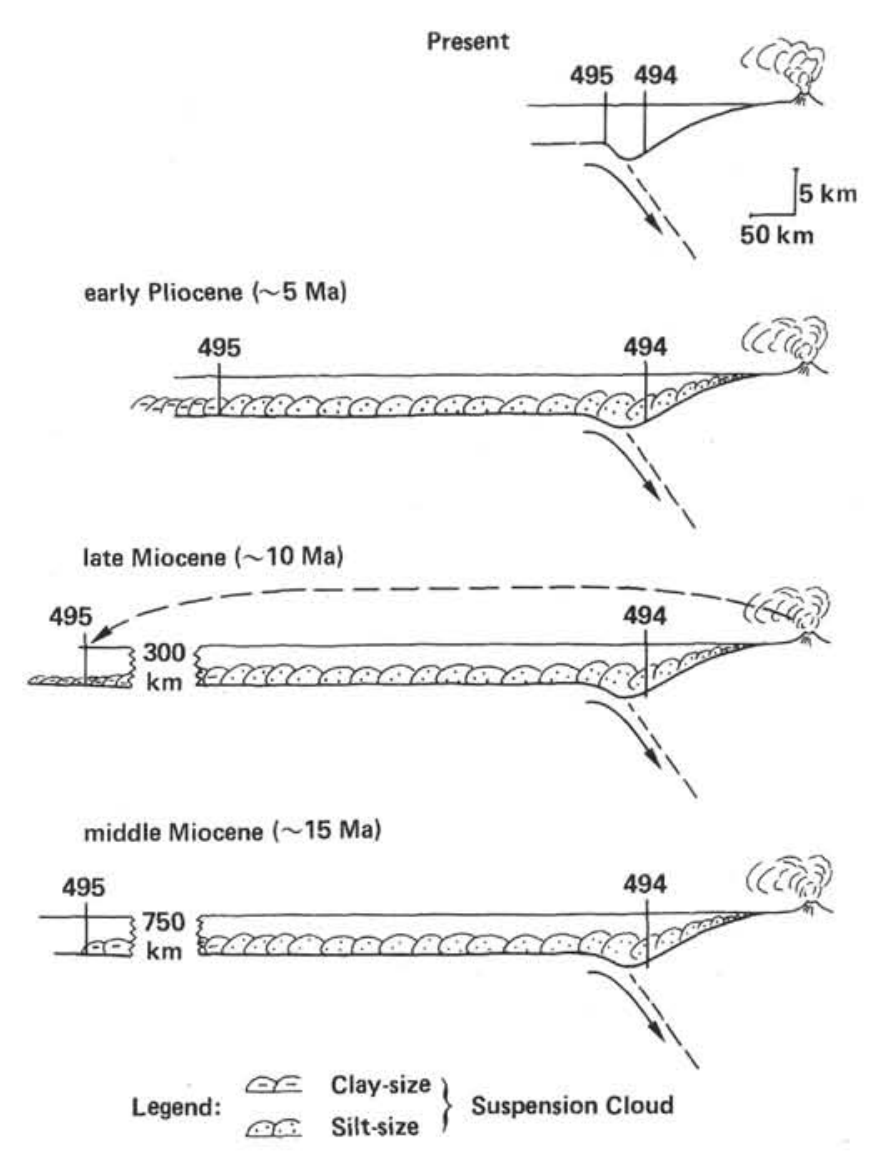

Figure 6. Model of the Cocos Plate movement and the arrival of claysize terrigenous mud $\sim 15 \mathrm{Ma}$ (bottom), of $>20-\mu \mathrm{m}$ volcanic glass $\sim 10 \mathrm{Ma}$, of $>20-\mu \mathrm{m}$ terrigenous material at Site $495 \sim 5 \mathrm{Ma}$, and the situation at present (top).

proposed by Minster and Jordan (1978). And Site 495, on the Cocos Plate, now about $170 \mathrm{~km}$ from the shore, would have been about $1100 \mathrm{~km}$ from the nearest Middle American volcanoes (Fig. 6). This interpretation would be in harmony with G. P. L. Walker's diagram (1971) showing a median diameter of pyroclastic fall deposits of about $20 \mu \mathrm{m}$ for such a distance.

Colorless shards of nearly the same refractive indexes as shown in Figure 3 were found by Kowsmann (1973) in the Panama Basin. He suggests an explosive mode of eruption for them and thinks that "they were ejected high enough to be entrained in the strongest easterlies and carried for considerable distances."

In the early Pliocene, a distinct increase of feldspars in the 20 - to $63-\mu \mathrm{m}$ fraction (Fig. 4) indicates a strong increase of terrigenous sediments. In Figure 6, it is suggested that these grains were transported in suspension clouds, as in the middle Miocene. The alternative is again an eolian transport, which would, however, imply a rather sudden addition of "andesitic" plagioclases to the "rhyolitic" glass that was continuously supplied. One would expect at least an addition of intermediate glass as well. The feldspar grains are not coated with glass. At this time, about $5 \mathrm{Ma}$, Site 495 was about 600 $\mathrm{km}$ away from the shore. The subaqueous cloud was evidently able to travel over this distance, passing the slope and even the trench (Fig. 6). Zeolites are sub- 
ordinate in this site, except for an increase of clinoptilolite in the manganiferous chalk on top of the basalt (see the section on Diagenesis).

Shiki et al. (this volume) investigated Core 4 from the Quaternary of Site 495, from which we had only Core 6. They found shallow water benthic foraminifers, pollen, plant fragments, and some terrigenous mineral grains such as quartz, feldspar, detrital clay minerals, and land-derived volcanic debris. They suggested transport by suspension in a layer detached from the near bottom turbidity current layer, which came down through a canyon on the continental slope and crossed the trench. This is in full agreement with our interpretation of the sediments at this Site beginning with the middle Miocene.

The accumulation of opal in the heavy fraction (Fig. 4) from Cores 34 and 37 (Hole 495) is caused by partial replacement (or coating?) of radiolarian tests by an opaque mineral (possibly pyrite).

\section{Trench (Sites 499 and 500)}

Because we did not investigate turbidites, only a few samples were considered. Because the sampling was not done at stratigraphically equivalent levels in the two holes, the mineralogical differences may not be significant. According to Table 3, kaolinite and illite do not appear before the late Pliocene at Site 499. Most conspicuous is the high zeolite content in the Quaternary part of the trench (Fig. 5). A relation with the turbidites is probable, because these are rich in volcanogenic components (Harrison et al., this volume). There is a tendency for the volcanic glass to have a more acid composition in the trench compared with the other environments (Fig. 3).

\section{Slope (Sites 494, 496, 497)}

\section{Site 494 (mainly Hole 494A, Fig. 7)}

This site, which is nearest to the trench without actually being in it, was expected to show interesting tectonic features, e.g., accretion, slumping, or subduction erosion (von Huene, Aubouin, et al., 1980). It yielded quite a normal profile, however, from Quaternary down to and including Upper Cretaceous rock and sediment.

Plant remains, micritic limestone fragments, and skeletal fragments "attest to a provenance from areas of much shallower depth"' (Harrison et al., this volume). This is in harmony with the composition of the clay fraction (Table 3 ), which is characterized by illite, kaolinite, and chlorite (the last in slope positions only), as well as smectite. It is also confirmed by the dominance of clastic feldspars (plagioclase) and subordinate quartz in the coarse silt fraction.

Suspension clouds deriving from the shelf and the Guatemalan mainland are responsible for supplying these materials, beginning at the Upper Cretaceous. This means that a slope position is indicated by the terrigenous material for the whole period considered.

Skeletal opal is subordinate in this site, mainly because of the large amount of terrigenous sediments. If they lessen, e.g., from middle Eocene to lower Miocene (low sedimentation rates, according to Thompson, this volume), the percentage of opal is increased. It is difficult to understand why a considerable admixture of brownish glass fragments ("bn" in Fig. 4) occurs only at this site. At Site 496 they are only subordinate. This suggests differences in supply.

Opal is very sparse in the Upper Cretaceous sample, because it is not stable in sediments of this age (Keene, 1976).

\section{Sites 496 and 497}

Land-derived feldspar, quartz, illite, kaolinite, and chlorite are dominant in the sequences cored in these holes (16 samples from Hole 497 were investigated but not included in the diagram). The composition is similar to that of Hole 494A, although opal and zeolites are more common in Hole 496 than in Hole 494A.

\section{ACKNOWLEDGMENTS}

Drs. Klaska, Oehlschlegel, and Riedel offered helpful advice. We are particularly indebted to Helmut Beiersdorf, Hans-Ulrich Schmincke, and Reinhard Hesse for valuable criticism and suggestions. Reinhard Hesse also provided the samples used in our study. H. Wiedner, N. Büllesbach, R. Sobanski, and C. Satilmis helped in the sample preparation; B. Kemper did the typing; R. Schumacher drafted the figures. The authors are grateful for this support.

\section{REFERENCES}

Alietti, A., 1972. Polymorphism and crystal-chemistry of heulandites and clinoptilolites. Am. Mineral., 57:1448-1462.

Biscaye, P., 1965. Mineralogy and sedimentation of Recent deep-sea clay in the Atlantic Ocean and adjacent seas and oceans. Bull. Geol. Soc. Am., 76:803-832.

Boles, J. R., 1972. Composition, optical properties, cell dimensions, and thermal stability of some heulandite group zeolites. Am. Mineral., 57:1463-1493.

Boles, J. R., and Wise, W. S., 1978. Nature and origin of deep-sea clinoptilolites. In Sand, L. B., and Mumpton, F. A. (Eds.), Natural Zeolites, Occurrence, Properties, Use: New York (Pergamon Press), pp. 235-243.

Hay, R. L., 1978. Volcanic ash-diagenesis. In Fairbridge, R. W., and Bourgeois, J. (Eds.), The Encyclopedia of Sedimentology: Stroudsburg, Pennsylvania (Dowden, Hutchinson \& Ross), pp. $850-851$.

Iijima, A., 1978. Geological occurrences of zeolite in marine environments. In Sand, L. B., and Mumpton, F. A. (Eds.), Natural Zeolites, Occurrence, Properties, Use: New York (Pergamon Press), pp. 175-198.

Kastner, M., and Stonecipher, S. A., 1978. Zeolites in pelagic sediments of the Atlantic, Pacific, and Indian Oceans. In Sand, L. B., and Mumpton, F. A., (Eds.), Natural Zeolites, Properties, Occurrence, Use: New York (Pergamon Press), pp. 199-220.

Keene, J. B., 1976. The distribution, mineralogy, and petrography of biogenic and authigenic silica from the Pacific basin [Ph.D. dissert.]. University of California, San Diego, Scripps Institute of Oceanography.

Kowsmann, R. O., 1973. Coarse components in surface sediments of the Panama basin, eastern equatorial Pacific. J. Geol., 81: 473-494.

Minster, J. B., and Jordan, T. H., 1978. Present-day plate motions. J. Geophys. Res., 83:5331-5354.

Pichler, H., and Weyl, R., 1973. Petrochemical aspects of Central American magmatism. Geol. Rundsch., 62:357-396.

Reynolds, R. C. J. R., and Hower, J., 1970. The nature of interlayering in mixed-layer illite-montmorillonites. Clays Clay Miner., 18:25-36.

Schmincke, H.-U., in press. Ash from vitric muds in deep sea cores from the Mariana trough and fore-arc region (South Philippine Sea) (Sites 453, 454, 455, 458, 459, SP). In Hussong, D., Uyeda, S., et al., Init. Repts. DSDP, 60: Washington (U.S. Govt. Printing Office). 


\section{HEINEMANN, H. FÜCHTBAUER}

Seibold, E., 1978. Mechanical processes influencing the distribution of pelagic sediments. Micropaleontology, 24:407-421.

von Huene, R., Aubouin, J., et al., 1980. Leg 67: The Deep Sea Drilling Project Mid-America Trench transect off Guatemala. Geol. Soc. Am. Bull., 91, Pt. I:421-432.

von Rad, U., Riech, V., and Rösch, H., 1977. Silica diagenesis in continental margin sediments off northwest Africa. In Lancelot, Y.,
Seibold, E., et al., Init. Repts. DSDP, 41: Washington (U.S. Govt. Printing Office), 879-905.

Walker, G. P. L., 1971. Grain-size characteristics of pyroclastic deposits. J. Geol., 79:696-714.

Windom, H. L., 1969. Atmospheric dust records in permanent snow fields: implications to marine sedimentation. Geol. Soc. Am. Bull., 80:761-782.

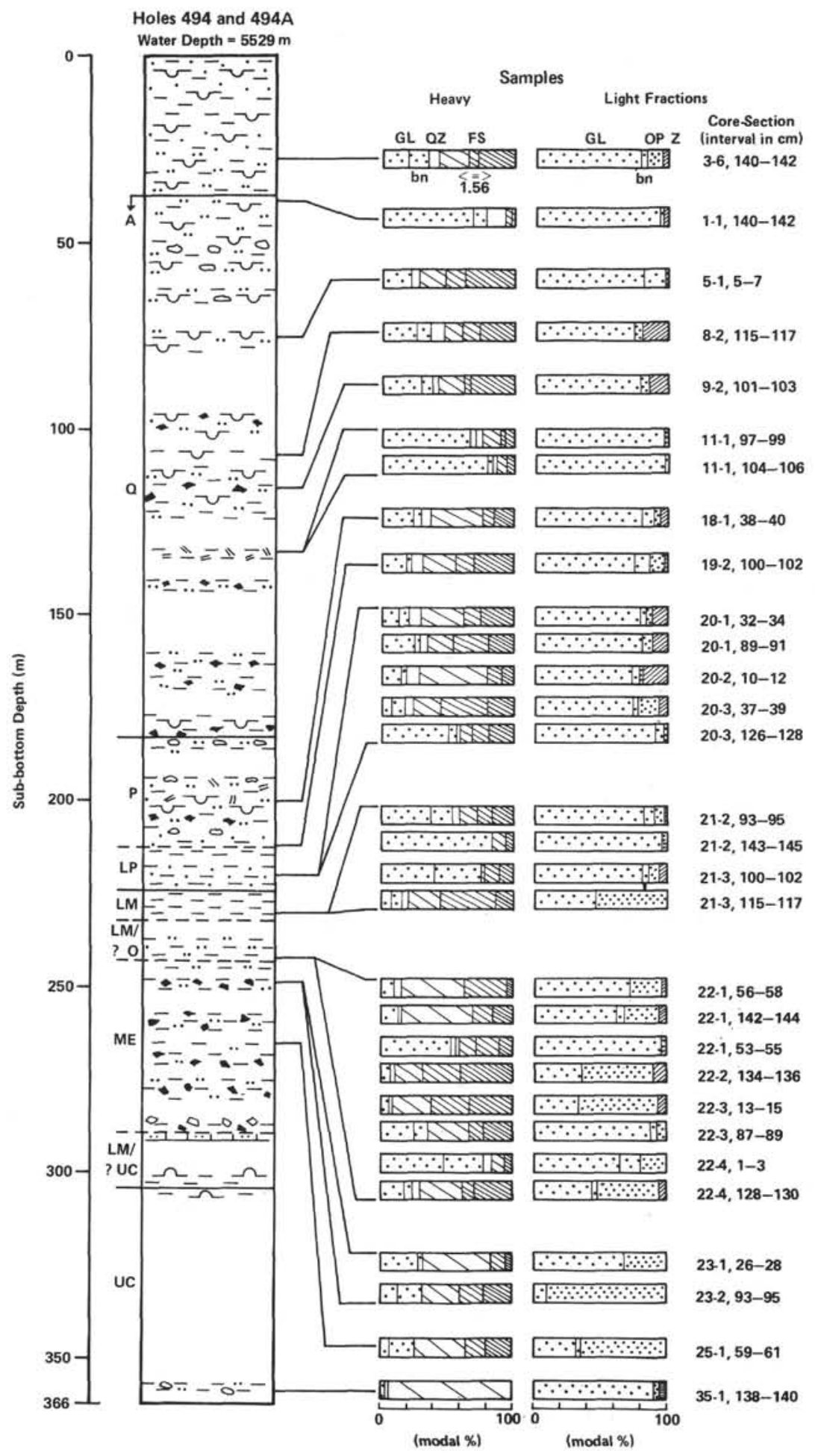

Figure 7. Holes 494 (uppermost sample only) and 494A from the lower slope; individual samples. (Legend: white "pebbles" = pebbly mudstone and black "pebbles" = drilling breccia in the graphic lithology column. A with arrow indicates the start of Hole 494A samples. See Fig. 4 caption for explanation of age abbreviations. Also, $\mathrm{GL}=$ glass, $\mathrm{bn}=$ brown, $\mathrm{QZ}=$ quartz; FS $=$ feldspar, $n<1.56, n=1.56, n>1.56$, OP = opal, $\mathrm{Z}=$ zeolites, undifferentiated.) 